\title{
EFFECTS OF ARTIFICIAL SHADING AND IRRIGATION WITH BRACKISH WATER ON THE INITIAL DEVELOPMENT OF Anadenanthera colubrina(Vell.) Brenan PLANTS
}

\author{
Luciana Luzia Pinho 2* $^{-}$, Claudivan Feitosa de Lacerda ${ }^{2} \odot$, João Alencar de Sousa ${ }^{3} \odot$, Alisson Moura

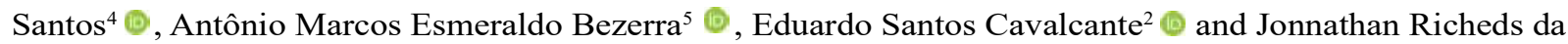 \\ Silva Sales ${ }^{2}$

\footnotetext{
${ }^{1}$ Received on 21.09.2021 accepted for publication on 13.12.2021.

${ }^{2}$ Universidade Federal do Ceará, Programa de Pós-Graduação em Engenharia Agrícola, Fortaleza, CE - Brasil. E-mail: <englucianaufc@ gmail.com>,<cfeitosa@ufc.br>,<educavalcanteufc@gmail.com> and <jonnathanagro@gmail.com>.

${ }_{3}^{3}$ Embrapa Agroindústria Tropical, Fortaleza , CE - Brasil. E-mail: <joao.alencar@embrapa.br>.

${ }^{4}$ Embrapa Florestas, Colombo, PR - Brasil. E-mail: <alisson.santos@embrapa.br>.

${ }^{5}$ Universidade Federal do Ceará, Departamento de Fitotecnia, Fortaleza, CE - Brasil. E-mail: <esmeraldo@ufc.br>.

*Corresponding author.
}

\begin{abstract}
The use of management strategies or changes in the cultivation environment can reduce the impacts of irrigation water salinity on plant development. Therefore, in this research, physiological responses, initial growth, and plant quality of Anadenanthera colubrina (Vell.) Brenan (Angico Branco) were evaluated under different levels of shading and electrical conductivity of the irrigation water, seeking to identify the most favorable conditions for the development of this species using brackish water. The experiment was carried out in randomized blocks with split plots and four replications. The plots were formed by four environments with different shading levels: 0 (full sun), 30,50, and 70\%, and the subplots, formed by five increasing levels of electrical conductivity of the irrigation water: $0.4,1.6,2.8,4.0$, and $5.2 \mathrm{dS} . \mathrm{m}^{-1}$. The following variables were evaluated: substrate electrical conductivity, leaf gas exchange, plant height, biomass production, and Dickson quality index at 40 days in a nursery. The use of artificial shading favored plant development and photosynthesis rate, even when irrigated with moderate and high salinity water. The DQI showed that $A$. colubrina plants presented higher quality index when produced under intermediate shading (30\% and $50 \%$ ), with yield losses below $20 \%$ when irrigated with water with electrical conductivity up to $2.8 \mathrm{dS} . \mathrm{m}^{-1}$.
\end{abstract}

Keywords: Angico Branco; Light intensity; Saline stress.

\section{EFEITOS DO SOMBREAMENTO ARTIFICIAL E IRRIGAÇÃO COM ÁGUAS SALOBRAS SOBRE O DESENVOLVIMENTO INICIAL DE PLANTAS DE}

\author{
Anadenanthera colubrina (Vell.) Brenan
}

\begin{abstract}
RESUMO - O uso de estratégias de manejo ou alterações no ambiente de cultivo podem reduzir os impactos da salinidade da água de irrigação sobre o desenvolvimento vegetal. Assim, nessa pesquisa foram avaliadas respostas fisiológicas, crescimento inicial e qualidade de plantas de Anadenanthera colubrina (Vell.) Brenan (Angico Branco) sob diferentes níveis de sombreamento e condutividade elétrica da água de irrigação, buscando-se identificar as condições mais favoráveis para o desenvolvimento dessa espécie utilizando-se águas salobras. O experimento foi realizado em blocos casualizados com parcelas subdivididas e quatro repetições. As parcelas foram formadas por quatro ambientes com diferentes níveis de sombreamento: 0 (pleno sol), 30,50 e 70\%, e as subparcelas, formadas por cinco níveis crescentes de condutividade elétrica da água de irrigação: 0,4, 1,6, 2,8, 4,0 e 5,2 dS. $\mathrm{m}^{-1}$. Foram avaliadas as variáveis: condutividade elétrica do substrato, trocas gasosas foliares, altura de plantas, produção de biomassa e indice de qualidade de Dickson aos 40 dias em viveiro. $O$ uso do sombreamento artificial favoreceu o desenvolvimento das plantas e a taxa de fotossíntese, mesmo quando irrigadas com água de moderada e elevada salinidade. O IQD mostrou que as plantas de A. colubrina
\end{abstract}

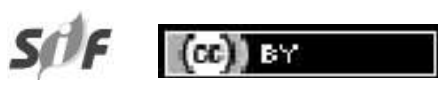

Revista Árvore 2022;46:e4607

http://dx.doi.org/10.1590/1806-908820220000007 
apresentaram maior índice de qualidade quando produzidas sob sombreamento intermediário (30\% e 50\%), com perdas no rendimento inferiores a $20 \%$ quando irrigadas com água com condutividade elétrica de até 2,8 dS. $m^{-1}$.

Palavras-Chave: Angico Branco; Intensidade luminosa; Estresse salino.

\section{INTRODUCTION}

Caatinga is the only exclusively Brazilian biome and is completely inserted in the Northeast Region. In this region, the burning of wood from native vegetation for energy production has become one of the main sources of income and a devastating form of environmental degradation (Araújo Filho, 2013; Santos et al., 2014). However, this biome has a delicate balance and suffers with the intemperate climate, which favors degradation, since the abiotic factors (drought, radiation, high temperatures and salinity of the water) exert great influence on the vegetation (Silva et al., 2017; Lima et al., 2018a; Rivas et al., 2020).

Salt stress limits the development of plant species (Matias et al., 2018), physiology and quality of plants (Lima et al., 2018a; Neves et al., 2018), including native Caatinga species (Bessa et al., 2017). The salinity problem is present in thousands of brackish water wells in the Brazilian semiarid region, mainly in the crystalline areas (Silva et al., 2007). These water sources could be used in productive activities, including the production of seedlings of forest species. In most cases, this is due to the sensitivity of the species to salinity, especially in the initial phase of development. However, these impacts can be lessened with the use of management strategies or even changes in the growing environment (Cavalcante et al., 2021; Lacerda et al., 2021).

Artificial shading can be an alternative to mitigate the effects of some abiotic factors, including salt stress, since it limits the solar radiation incident on the leaf surface and modifies the environmental conditions in order to improve plant development (César et al., 2014; Ahemd et al., 2016; Echer et al., 2019; Asghar et al., 2021).

The 'angico branco' (Anadenanthera colubrina) (Vell.) Brenan is a tree species native to Brazil, being found in several biomes, among them the Caatinga. Among the native forest species with the greatest economic potential, the angico stands out, and can be used for several purposes, such as urban forestation, recovery of degraded areas, animal feed, pharmaceutical industry, civil construction, energy generation, among others (Carvalho, 2003; Campos Filho and Sartorelli, 2015).

There is a growing demand for forestry technologies that allow an increase in productivity and quality of seedlings in non-traditional regions, especially for native species. Every year, new businesses emerge, guided mainly by the increase in production efficiency and environmental and economic sustainability. The objective of this study was to evaluate the initial development of (A. colubrina) plants, under different levels of shading and salinity of the irrigation water, through the analysis of biometric and physiological characteristics in the initial phase of development.

\section{MATERIAL AND METHODS}

The experiment was conducted at the Center of Education and Research in Urban Agriculture (NEPAU) of the Plant Science Department of the Federal University of Ceará (UFC), Pici campus, municipality of Fortaleza, Ceará, Brazil, located at the geographic coordinates $03^{\circ} 44^{\prime} 17^{\prime \prime} \mathrm{S}, 38^{\circ} 34^{\prime} 22^{\prime \prime}$ $\mathrm{W}$ and altitude of $19 \mathrm{~m}$, in the period from September to November 2020.

The experimental design used was a randomized blocks design with four repetitions. The plots were made up of four shading levels: 0 (full sun), 30, 50, and $70 \%$. The subplots were composed of five increasing levels of electrical conductivity of the irrigation water: $0.4,1.6,2.8,4.0$ and $5.2 \mathrm{dS} \mathrm{m}^{-1}$, totaling 80 experimental units.

For the conduction of the experiment, three environments built with wooden structures were used, measuring $2.8 \mathrm{~m}$ high, $6.1 \mathrm{~m}$ wide, and $9.0 \mathrm{~m}$ long. Both the roof and the sides of the structures were covered with black screens with shading of 30,50 , and $70 \%$. To compose the treatment in full sun, a

Revista Árvore 2022;46:e4607 
shaded fence was built on the sides to prevent outside interference.

Daily data on average temperature, relative humidity and global solar radiation were collected from the climatological station Fortaleza A305 of the National Institute of Meteorology (INMET, 2020), located at coordinates $03^{\circ} 48^{\prime} 56.5^{\prime \prime} \mathrm{S}, 38^{\circ} 32^{\prime} 16.1^{\prime \prime} \mathrm{W}$ and altitude of $20 \mathrm{~m}$, approximately $9.56 \mathrm{~km}$ from the experimental area. The average temperature during the period was $27.9^{\circ} \mathrm{C}$ and the average relative humidity was $67.5 \%$, while the global solar radiation had a daily average of $224.0 \mathrm{~W} \mathrm{~m}^{-2}$, for the full sun environment (INMET, 2020). For the other environments, the estimated average values were $156.8,112.0$, and 67.2 $\mathrm{W} \mathrm{m} \mathrm{m}^{-2}$, respectively under 30,50 , and $70 \%$ shading.

The seeds of 'angico branco' (A. colubrina) came from the Serra das Almas Natural Reserve (RNSA), located on the border between the municipalities of Crateús (CE) and Buriti dos Montes (PI) and implemented by the Caatinga Association. The angico seeds were sown in expanded polystyrene trays of 128 cells, with a volume of $23.60 \mathrm{~cm}^{3}$. The substrate used for sowing was composed of fine sand + vermicompost + soil (classified as Red-Yellow Argissolo) in a 1:1:1 ratio.

At 10 days after sowing (DAS), the seedlings were selected according to the uniformity of height, diameter, and number of leaves, and were transplanted into polyethylene plastic pots, with a volume of $7 \mathrm{~L}$, containing a $3 \mathrm{~cm}$ layer of gravel no. 0 on the bottom, in order to facilitate water drainage. The pots were filled with a substrate composed of fine sand, vermicompost, and soil in a 7:1:2 ratio, respectively, and had the following chemical characteristics: $\mathrm{pH}=$ 5.7; $\mathrm{EC}=0.3 \mathrm{dS} \mathrm{m}^{-1} ; \mathrm{Ca}=3.1 \mathrm{cmolc} \mathrm{kg}^{-1} ; \mathrm{Mg}=0.8$ cmolc kg-1 $; \mathrm{K}=0.39$ cmolc kg-1$; \mathrm{Na}=0.43$ cmolc kg1; $\mathrm{P}=116 \mathrm{mg} \mathrm{kg}^{-1}$. Before the beginning of the salt treatments, fertilization was performed, according to Gonçalves et al. (2012) with the doses of 50 of N, 150 of $\mathrm{P}$ and 50 of $\mathrm{K}$ in $\mathrm{mg} \mathrm{dm}^{-3}$ of substrate.

The levels of electrical conductivity of the irrigation water used to compose the saline treatments were obtained by dissolving the salts sodium chloride $(\mathrm{NaCl})$, calcium chloride $\left(\mathrm{CaCl}_{2} \cdot 2 \mathrm{H}_{2} \mathrm{O}\right)$, and magnesium chloride $\left(\mathrm{MgCl}_{2} \cdot 6 \mathrm{H}_{2} \mathrm{O}\right)$ in a $7: 2: 1$ ratio, added to well water with an initial electrical conductivity of $0.4 \mathrm{dS} \mathrm{m} \mathrm{m}^{-1}$. The $7: 2: 1$ ratio is a representative approximation for most water sources available for irrigation in the Northeast Region of Brazil (Medeiros, 1992).

The irrigations were done manually, with watering every two days, and the volume was determined by the difference between the volume of water applied, and the volume drained in reference pots previously selected for each treatment. In each irrigation, a leaching rate of $15 \%$ was adopted to avoid excessive salt accumulation in the root zone of the plants. At the end of the experimental period, the total volume of water applied in each treatment (shading and salinity) during the entire trial was determined (Table 1).

The determination of the electrical conductivity of the substrate at the end of the experiment was made according to Rhoades and Miyamoto (1990), with the measurement of the electrical conductivity of the substrate: water suspension (1:1 on a volume basis) made with a portable conductivity meter model CD860 , Instrutherm and values expressed in $\mathrm{dS} \mathrm{m}^{-1}$.

At 30 days after the beginning of the salt treatments, the rates of net photosynthesis $(A$, in $\left.\mu \mathrm{mol} \mathrm{m} \mathrm{m}^{-2} \mathrm{~s}^{-1}\right)$, stomatal conductance $\left(g s\right.$, in $\mathrm{mol} \mathrm{m} \mathrm{m}^{-2}$ $\left.\mathrm{s}^{-1}\right)$, transpiration $\left(E\right.$, in mmol $\left.\mathrm{m}^{-2} \mathrm{~s}^{-1}\right)$, and internal

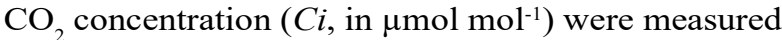
with a portable infrared gas analyzer, model LI-

Table 1 - Total volume of water consumed (average \pm standard error) by (A. colubrina) plants as a function of shading and electrical conductivity of irrigation water.

Tabela 1 - Volume total de água consumido (média \pm erro padrão) pelas plantas de (A. colubrina) em função dos níveis de sombreamento e condutividade elétrica da água de irrigação.

\begin{tabular}{lccc}
\hline \multirow{2}{*}{ ECw $\left(\mathrm{dS} \cdot \mathrm{m}^{-1}\right)$} & $70 \%$ & $50 \%$ & \multicolumn{2}{c}{ Water Consumption (L) } \\
\cline { 2 - 4 } & $5,624 \pm 0,33$ & $6,254 \pm 0,49$ & $7,740 \pm 0,32$ \\
\hline 0,4 & $5,489 \pm 0,22$ & $6,033 \pm 0,34$ & $6,571 \pm 0,27$ \\
1,6 & $4,211 \pm 0,19$ & $4,622 \pm 0,28$ & $5,630 \pm 0,34$ \\
2,8 & $4,132 \pm 0,61$ & $4,557 \pm 0,16$ & $5,166 \pm 1,17$ \\
4,0 & $3,483 \pm 0,27$ & $3,976 \pm 0,29$ & $4,6758 \pm 0,29$ \\
5,2 & & & $6,822 \pm 0,36$ \\
\end{tabular}


$6400 X T$, Licor, USA, with a light intensity of 1,800 $\mu \mathrm{mol} \mathrm{m} \mathrm{m}^{-2} \mathrm{~s}^{-1}$. The readings were taken in the morning, between 08:00 and 10:00 am, on the fully expanded leaves of each plant and under ambient conditions of air temperature and relative humidity, with constant $\mathrm{CO}_{2}$ concentration. Using the gas exchange data, the carboxylation efficiency $\left(A \mathrm{Ci}^{-1}\right)$ was calculated.

At 40 days after the beginning of the salt treatments, plant height and stem diameter were determined with a graduated ruler and digital caliper, respectively. Then, the plants were then divided into roots, stems and leaves and placed in paper bags to be dried in an oven with forced air circulation, maintaining the temperature around $65^{\circ} \mathrm{C}$ until they reached a constant weight.

To determine the quality of the plants, Dickson quality index (DQI) was calculated (Equation 1), according to Dickson et al. (1960), in which: $D Q I=\frac{T D B}{\frac{P H}{S D}+\frac{S D B}{R D B}}$

Eq. 1 where: DQI - Dickson quality index; TDB - total dry biomass (g); PH - plant height $(\mathrm{cm})$; SD - stem diameter (mm); SDB - shoot dry biomass (g); RDB root dry biomass $(\mathrm{g})$.

The data obtained were submitted to variance analysis and when significant by the $\mathrm{F}$ test $(\mathrm{p} \leq$ 0.05 ), the qualitative data (shading factor alone) were submitted to the Tukey test and the quantitative data were submitted to regression analysis, admitting error up to $5 \%$ probability and adopting the mathematical model based on the significance and the determination coefficient, using the statistical software SISVAR version 5.7 (Ferreira, 2014).

\section{RESULTS}

The substrate electrical conductivity $\left(\mathrm{EC}_{1: 1}\right)$, net photosynthesis $(A)$, carboxylation efficiency $\left(A C i^{-1}\right)$, plant height $(\mathrm{PH})$, root dry biomass (RDB), shoot dry biomass (SDB) and Dickson quality index (DQI) were significantly influenced by the interaction between the

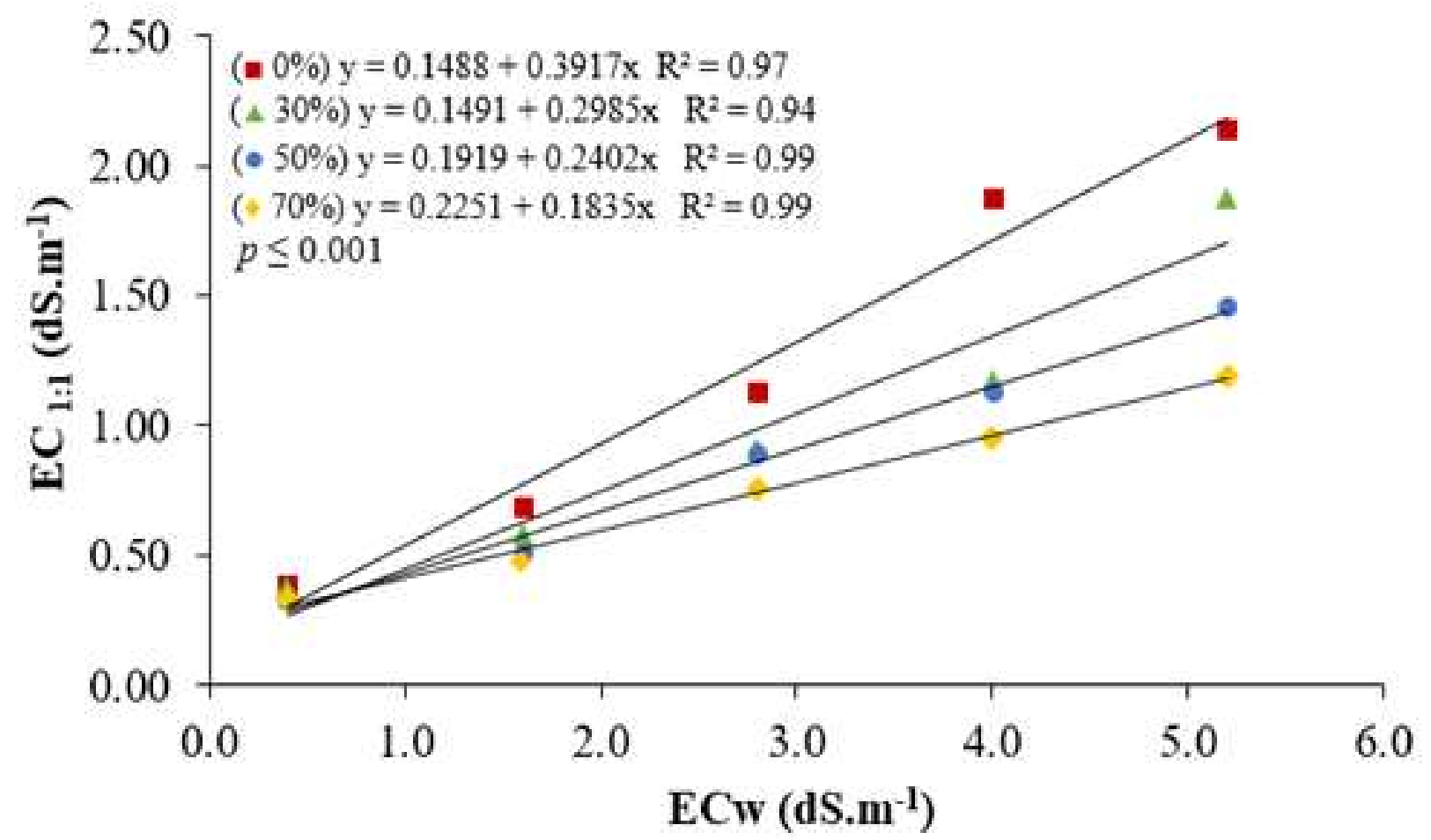

Figure 1-Electrical conductivity of the substrate $\left(\mathrm{EC}_{1.1}\right)$ grown with $(A$. colubrina $)$ plants under shading levels and electrical conductivity of irrigation water (ECW) at 40 days after planting in Fortaleza, CE, Brazil.

Figura 1 - Condutividade elétrica do substrato (CE1:1) cultivado com plantas de (A. colubrina) sob niveis de sombreamento e condutividade elétrica da água de irrigação (CEa) aos 40 dias após o plantio em Fortaleza, CE, Brasil.

Revista Árvore 2022;46:e4607 
factors studied $(\mathrm{p}<0.05)$. Stomatal conductance $(g s)$, transpiration $(E)$ and internal $\mathrm{CO}_{2}$ concentration $(C i)$ were influenced by shading and salinity factors alone $(\mathrm{p}<0.05)$.

The electrical conductivity of the substrate, in the substrate:water extract $(1: 1)$ increased linearly with the levels of electrical conductivity of the irrigation water, and the greatest accumulation of salts was observed in the full sun environment (Figure 1). Increases in $\mathrm{EC}_{1: 1}$ values of $0.39,0.29,0.24$, and 0.18 $\mathrm{dS} \mathrm{m}^{-1}$ were found in the full sun, 30, 50, and 70\% shaded environments, respectively, for each increase in the electrical conductivity of the irrigation water (Figure 1).

Stomatal conductance was significantly influenced by the isolated effects of shading and irrigation water electrical conductivity (Figure 2). In relation to the levels of shading, it was observed that the use of shading screens provided greater stomatal conductance of $A$. colubrina plants, with the highest values of $g s$ observed in the environment with $50 \%$ shade $\left(0.25 \mathrm{~mol} \mathrm{~m}^{-2} \mathrm{~s}^{-1}\right)$, which presented statistically superior mean values than plants in full sun $(0.16 \mathrm{~mol}$ $\mathrm{m}^{-2} \mathrm{~s}^{-1}$ ) (Figure 2A). On the other hand, the electrical conductivity of the irrigation water caused a linear decreasing response in $g s$, with a reduction rate of $0.0324 \mathrm{~mol} \mathrm{~m}^{-2} \mathrm{~s}^{-1}$ per unit $\mathrm{dS} \mathrm{m} \mathrm{m}^{-1}$ (Figure 2B).

Photosynthetic rates were influenced by the association of the effects of solar radiation and salinity (Figure 2C). In general, reductions in photosynthetic rates occurred in all environments with increasing levels of electrical conductivity of the water. The most pronounced reductions occurred in full sun, due to the more depressive action of the combination between the factors analyzed, expressing more intense reductions when compared to the other environments (Silva et al., 2017).

By deriving the equations of the regression curves, the maximum values of $A$ were obtained at $0.52,1.99$, and $2.61 \mathrm{dS} \mathrm{m}^{-1}$ for the full sun, 50 and $70 \%$ shaded environments respectively, showing that shading attenuates the effect of salt stress. In the treatments with higher salt concentrations, in full sun, the values were lower than in the other treatments (Figure 2C).

Carboxylation efficiency was reduced at all shading levels with increasing water conductivity
(Figure 2D), with greater reductions in the full sun environment and with the lowest $A C i^{-1}$ ratios. The maximum values of the $A C i^{-1}$ ratio were estimated at salinity levels of $1.19,1.81,2.38$, and $3.5 \mathrm{dS} \mathrm{m}^{-1}$ in full sun, 30, 50 and $70 \%$ shade, respectively. These results indicate that plants that were exposed to the highest radiation levels showed greater $\mathrm{CO}_{2}$ losses with increasing salt stress.

Transpiration was significantly influenced by the isolated effects of the shading and salinity factors. It can be seen that the shading screens promoted a higher transpiration rate in $A$. colubrina plants, and the environment with $50 \%$ shading provided the highest averages $\left(5.5 \mathrm{mmol} \mathrm{m}^{-2} \mathrm{~s}^{-1}\right)$, not differing from the other shading levels, but being statistically higher than plants that were in full sun $\left(3.58 \mathrm{mmol} \mathrm{m}^{-2} \mathrm{~s}^{-1}\right)$ (Figure 2E). In relation to salinity, the averages fitted a decreasing linear model, showing that transpiration decreased in plants that were subjected to the highest salinity levels, with decreases of $0.65 \mathrm{mmol} \mathrm{m}^{-2} \mathrm{~s}^{-1}$ for each increase in water electrical conductivity (Figure 2F).

The plant height data (Figure 3A) indicate that there was solar radiation stress on the plants in the full sun environment, which showed smaller heights, even under non-saline conditions, but with a reduction in height as the electrical conductivity of the water increased. It is possible then to infer that in full sun, the higher level of incident solar radiation promotes interference in the height growth of the Angico plants, as well as the increase in the levels of electrical conductivity of the irrigation water.

The relative reductions in plant height, comparing the lowest and highest salinity treatments, were 52.3, $70.8,51.7$, and $45.2 \%$ in the full sun, 30, 50, and $70 \%$ shading environments, respectively. There was a greater reduction in height, in relation to salinity in the $30 \%$ shaded environment, showing that the $30 \%$ shading is not enough to neutralize the harmful effects of salinity, since the treatment in full sun, also since the lowest dosages, had the lowest values of plant height.

Root dry biomass showed linear reductions with increasing irrigation water conductivity (Figure 3B). Reductions of $86.7,56.4,54.0$, and $63.2 \%$ occurred between the salinity extremes $\left(0.4\right.$ and $\left.5.2 \mathrm{dS} \mathrm{m}^{-1}\right)$ in full sun, 30,50 , and $70 \%$ shade, respectively. The

Revista Árvore 2022;46:e4607 

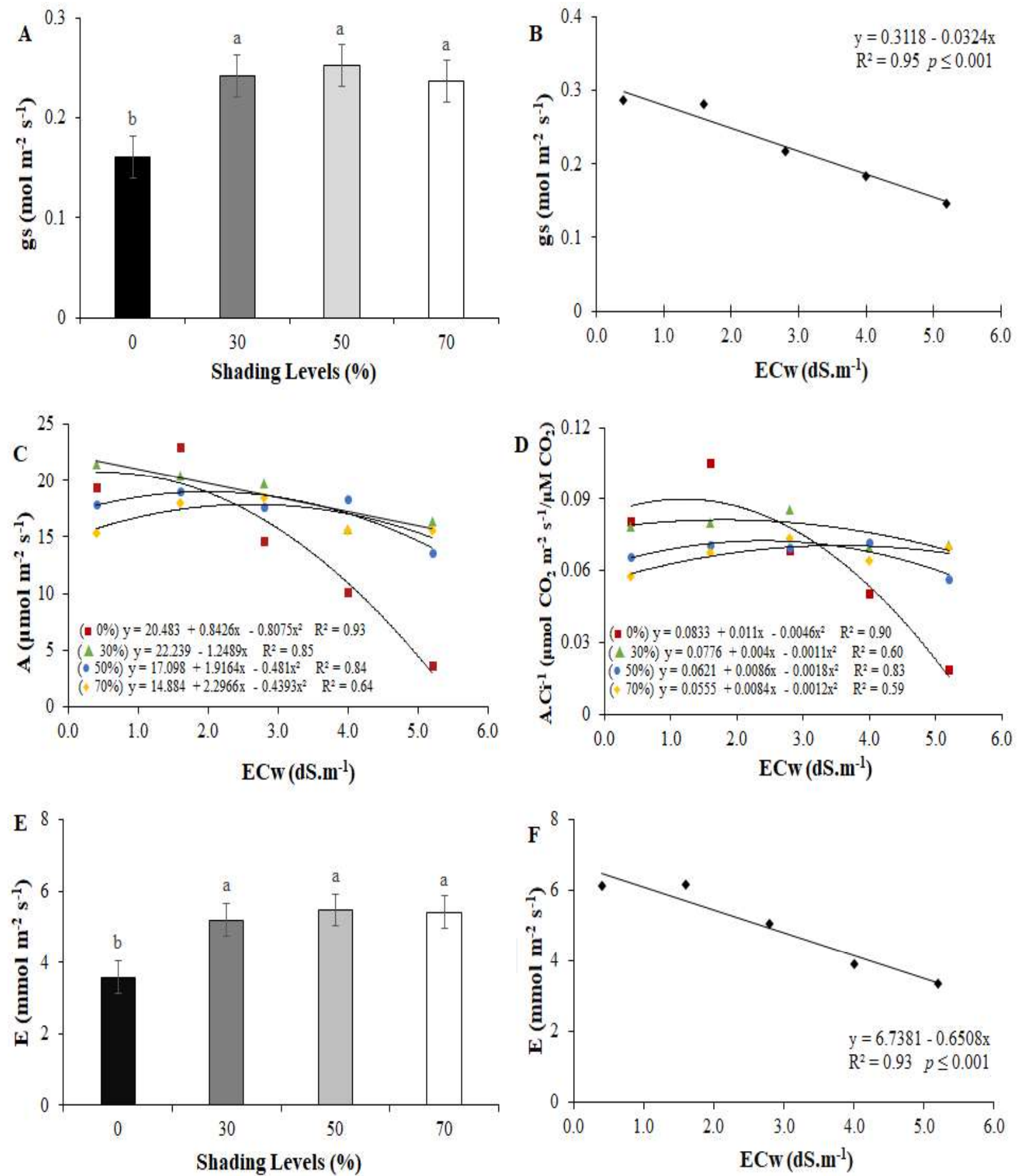

Figure 2 - Stomatal conductance (A and B), net photosynthesis $(\mathrm{C})$, carboxylation efficiency (D) and transpiration $(\mathrm{E}$ and $\mathrm{F})$ of $(A$. colubrina) plants under shading levels and electrical conductivity of irrigation water (ECw).

Figura 2 - Condutância estomática (A e B), fotossíntese líquida (C), eficiência de carboxilação (D) e transpiração ( $E$ e $F)$ das plantas de (A. colubrina) sob niveis de sombreamento e condutividade elétrica da água de irrigação (CEa). 

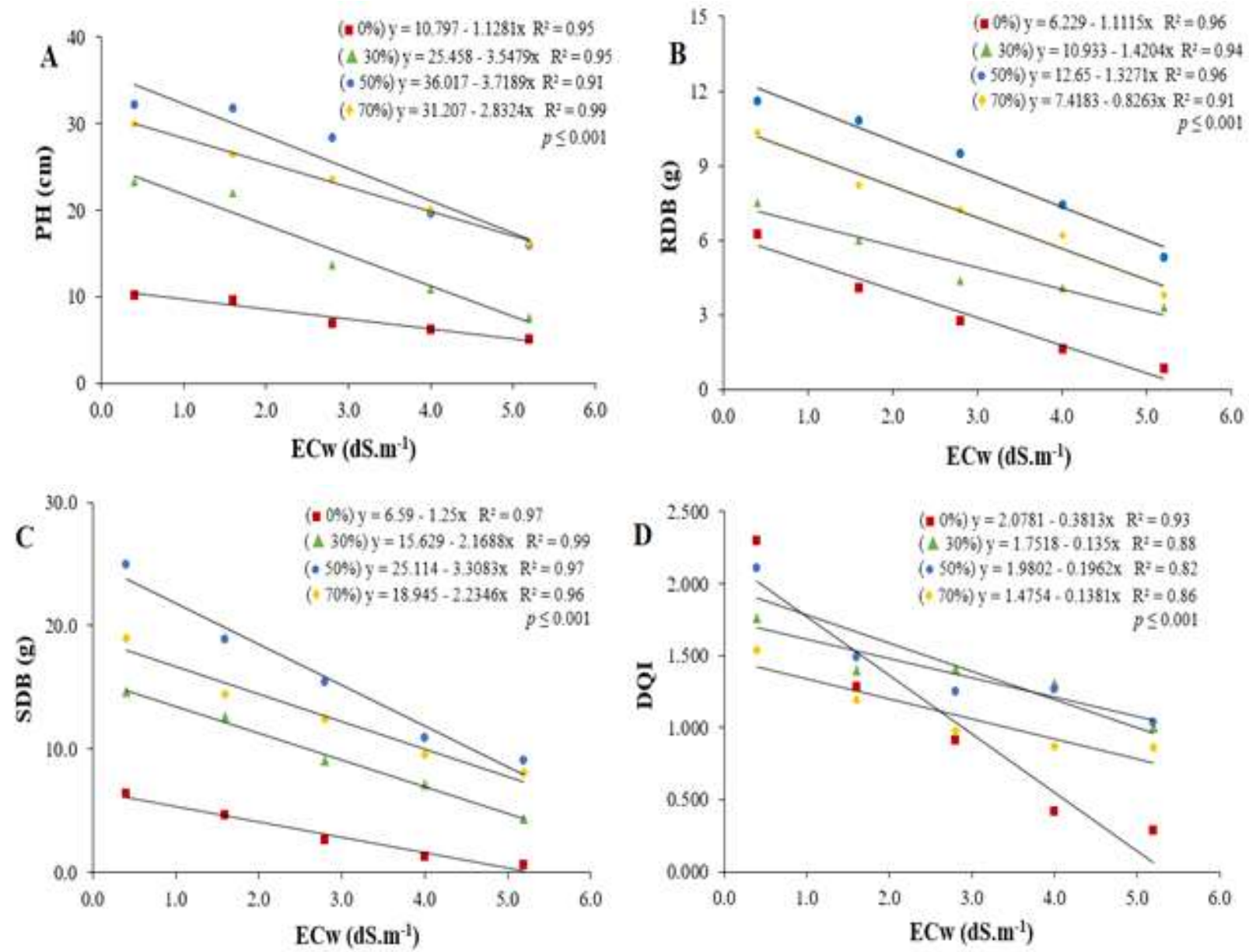

Figure 3 - Plant height (A), root dry biomass (B), shoot dry biomass (C) and Dickson quality index (D) of (A. colubrina) plants under shading levels and electrical conductivity of irrigation water $(\mathrm{ECw})$.

Figura 3 - Altura de plantas (A), biomassa seca das raizes (B), biomassa seca da parte aérea $(C)$ e indice de qualidade de Dickson (D) das plantas de (A. colubrina) sob níveis de sombreamento e condutividade elétrica da água de irrigação (CEa).

highest values in the percentage reduction of the RDB of the plants occurred under $70 \%$ shading and in full sun.

In all environments studied, $A$. colubrina plants had marked reductions in shoot dry biomass in increasing treatments of irrigation water salinity (Figure 3C). The percentage reductions between the highest and lowest salinity levels in each environment were $79.5,70.1,63.6$, and $57.6 \%$ in full sun, 30,50 , and $70 \%$ shade, respectively.

The Dickson quality index (DQI) decreased linearly in all environments studied with increasing salinity of irrigation water, with this reduction being accentuated in plants in full sun (Figure 3D). In this environment, the reductions reached 47.5 and $95.0 \%$ at salinities of 2.8 and $5.2 \mathrm{dS} \mathrm{m}^{-1}$. The environments with intermediate shading levels (30 and 50\%) were those that presented the highest average DQI values, indicating greater potential for establishment in the field. On the other hand, the $70 \%$ environment was the one that presented the lowest average DQI values under low salinity conditions, surpassing the full sun environment only at salinities higher than $3.0 \mathrm{dS} \mathrm{m}^{-1}$.

\section{DISCUSSION}

The increase in $\mathrm{EC}_{1: 1}$ values can be attributed to the higher incidence of solar radiation in environments with less shading, causing greater absorption of thermal energy by the substrate surface, consequently increasing temperature values and water consumption

Revista Árvore 2022;46:e4607 
(Yuan et al., 2019), as observed in the present study (Table 1), favoring greater contribution of salts to the system.

The variations in stomatal conductance values (Figure 2A and 2B) are due to the fact that the shadier environments tend to be more humid, since the substrate surface has less evaporation, which keeps the stomata open longer, since the stomatal response is related to the plant's water dynamics (Freitas et al., 2020). On the other hand, the increase in the concentration of salts in the substrate causes a reduction in the water potential, compromising water uptake by the roots and causing stomatal closure as a stress tolerance mechanism, reducing water losses (Silva et al., 2014).

The behavior of $g s$ with respect to shading can be attributed to the greater thermal comfort provided by the screens, demonstrating that there is sensitivity of $g s$ with increasing temperature, since high temperatures increase the effect of vapor pressure deficit (VPD) and can lead to stomatal closure, minimizing water loss (Taiz et al., 2017). They also mention that in most C3 plants, stomatal closure is associated with high VPD values, especially when growing in environments with low soil water availability. Thus, these limitations in stomatal conductance can protect plants by preventing excessive water loss and enabling survival under stress conditions (Urban et al., 2017).

The reduced photosynthetic performance (Figure $2 \mathrm{C}$ ) in the environments with higher incident radiation levels and the higher salinity levels can also be attributed to the indirect effects of high temperatures, causing both inhibition of photosynthetic enzyme activity and limitations in stomatal conductance, reducing the assimilation of atmospheric $\mathrm{CO}_{2}$ and consequently restricting the photosynthetic rate (Tan et al., 2017; Silva et al., 2019). In addition, because it is considered a $\mathrm{C} 3$ plant, angico adapts better to low-light conditions than C4 or CAM plants, as well as being an early secondary species, explaining why there were no marked reductions in photosynthetic rates in plants that were in shaded environments (Taiz et al., 2017).

Regarding carboxylation efficiency (figure 2D), shading partially attenuated the effects of salt stress. In the three levels of shading used, there was a greater efficiency of carboxylation, even with the increase in the electrical conductivity of the irrigation water, while in the full sun environment, the reduction was more pronounced. The greater reductions in the full sun environment may indicate the possibility of inhibition of the RuBisCo enzyme due to heat stress, which will also cause biochemical limitations on photosynthesis, decreasing carboxylation efficiency (Campelo et al., 2015; Perdomo et al., 2017; Silva et al., 2019). The high values of internal $\mathrm{CO}_{2}$ concentration associated with the increase in stomatal conductance at the higher levels of shading, can justify the higher instantaneous carboxylation efficiency, which occurred due to the availability of ATP and NADPH and substrate for RuBisCo (Silva et al., 2015; Tan et al., 2017).

Similar results were observed by Andrade et al. (2019), who observed reductions in carboxylation efficiency in Eucalyptus spp. clones with increasing soil salinity levels, observing strong correlation with photosynthesis data, which was also observed in the present study. Scalon et al. (2015) also observed reductions in instantaneous carboxylation efficiency in Hancornia speciosa seedlings as a result of limitations in RuBisCo enzyme activity caused by water deficit. The authors state that after the reduction in stomatal conductance the efficiency of carboxylation is affected, pointing out that under conditions of low water potential, with the decrease in stomatal conductance, the rate of $\mathrm{CO}_{2}$ assimilation and transpiration are also reduced.

The behavior of transpiration followed the same trend as stomatal conductance (Figure 2A), showing the reduction of plant water loss through stomatal closure, according to the conditions of water availability. Under conditions of water availability, plants generally exhibit high transpiration rates, while as water availability reduces, the plant closes stomata to reduce water loss, also reducing transpiration (Felsemburgh et al., 2016). Similarly, it happens with respect to the increase in salinity, since the absorption of water is restricted by the osmotic effect, leading to stomatal closure not only to reduce water loss, but also as a way to regulate the amount of water absorbed, also reducing the absorption of salts and consequently reducing the transpiration rate (Freire et al., 2021).

The reduction in RDB production, with increasing salinity, is due to the fact that the roots are the plant organs that have direct contact with the salts present in the soil and need to adapt to maintain

Revista Árvore 2022;46:e4607 
growth and the absorption of water and nutrients. With increasing soil salt concentration the root mass is reduced, affecting the growth rate of the main root and lateral roots and inhibiting the formation of new lateral roots (Zelm et al., 2020). Corroborating with the results obtained, Lima et al., (2018b) observed that, dry matter accumulation in Hazel sterculia seedlings was negatively affected by increasing salinity levels, showing relative losses of up to $53 \%$ between the control treatment $\left(1.0 \mathrm{dS} \mathrm{m}^{-1}\right)$ and the one with the highest saline level $\left(5.1 \mathrm{dS} \mathrm{m}^{-1}\right)$. As for the shading levels, the high percentage of reduction in the $70 \%$ environment was due to the fact that the shading level was very high, promoting limitations in photosynthetic activity and consequently lower increase in RDB (Ballaré and Pierik, 2017).

The lower SDB values in the treatments with higher salinity, are attributed to the decrease in turgidity caused by water deficit and changes in cell wall properties, which is accentuated when the plants are in environments with higher levels of incident solar radiation, decreasing cell expansion and plant growth. In addition, the photosynthetic limitations observed previously, may also be contributing to such results, since with the stomatal closure observed at higher salt concentrations, there is less $\mathrm{CO}_{2}$ assimilation, affecting the production of photoassimilates by the plant (Freitas et al., 2014).

In general, the reduction in plant growth, measured by height (Figure 3A) and biomass production (Figure $3 \mathrm{~B}$ and $3 \mathrm{C}$ ) may have been caused by stomatal closure, caused by the osmotic effect of irrigation water salts, as a way to reduce water loss by transpiration since water uptake is reduced, restricting the photosynthetic capacity of the plant, consequently limiting development (Taiz et al., 2017; Kumar et al., 2018). Another factor that may have contributed to the reduction in plant height, under higher salinity levels, is the toxicity by $\mathrm{Na}^{+}$and $\mathrm{Cl}^{-}$ions, causing nutritional imbalance (Araújo et al., 2018).

The presence of high levels of radiation and high temperatures, intensify the effects of salt stress on the growth and development of plants, since the assimilation of $\mathrm{CO}_{2}$ is directly related to higher water availability, which is affected by high exposure to solar radiation and the osmotic effect of salt, and may even compromise the establishment of plants under field conditions (Long et al., 1994; Morais et al., 2017). The milder temperatures, provided by the environments with higher levels of shading, favored the water status of the plants, enabling improvement in photosynthetic activity and turgidity, parameters that are necessary for growth (Pacheco et al., 2013).

The reduction in DQI with increasing salinity may have occurred due to reduced water uptake by plants as a result of the osmotic effect, affecting development and reflecting on height, diameter, and biomass production, which are used in determining DQI (Alves et al., 2019). Similarly, plants grown in full sun had their development influenced by the environmental conditions that influenced water availability, while at extreme levels of shading $(70 \%)$, there was a reduction in the production of photoassimilates used for development and reflected in the seedling quality index.

According to the results obtained, it was observed that the angico plants presented variations in their development depending on the level of shade provided, where they showed better development in intermediate light conditions. These results are in accordance with the species' classification in the successional group, which is classified as early secondary (Carvalho, 2003), that is, it needs less light than pioneer species, tolerating partial shading in the juvenile phase (Almeida, 2016).

\section{CONCLUSIONS}

The use of artificial shading favored the initial development of $A$. colubrina plants, with greater growth and higher photosynthetic rates at moderate and high salinity levels, when compared to the full sun environment.

At 40 days of $A$. colubrina plants in nursery, the conditions for production were evidenced by physiological responses, growth, quality index and with intermediate shading (30 or $50 \%$ ), tolerating irrigation with brackish water with electrical conductivity up to $2.8 \mathrm{dS} \mathrm{m}^{-1}$.

\section{AUTHOR CONTRIBUTIONS}

All authors made essential contributions to the elaboration of this work. PINHO LL was responsible for conducting the experiment and the initial writing of the manuscript. CAVALCANTE ES and SALES JRS 
assisted in conducting the experiment and to review and correct the work. SANTOS AM contributed with the supervision of the methodology and correction. LACERDA CF, SOUSA JA and BEZERRA AME contributed to the provision of resources and acted in the supervision, validation and review of the work as a whole.

\section{REFERENCES}

Ahemd HA, Al-Faraj AA, Abdel-Ghany AM. Shading greenhouses to improve the microclimate, energy and water saving in hot regions: a review. Scientia Horticulturae. 2016;201:36-45. doi: 10.1016/j.scienta.2016.01.030

Almeida DS. Recuperação Ambiental da Mata Atlântica. Ilhéus: Editus; 2016. v. 3

Alves LS, Véras MLM, Melo Filho JS de, Irineu THS, Dias TJ. Salinity irrigation water and application of bovine biofertilizer for growth and quality. Irriga. 2019;24(2):254-273. doi: 10.15809/ irriga.2019v24n2p254-273

Andrade JR de, Maia Júnior SO, Santos AFS, Silva VM da, Bezerra LT, Silva JRR da, et al. Photosynthetic performance in Eucalyptus clones cultivated in saline soil. Emirates Journal of Food and Agriculture. 2019;31(5):368-379. doi: 10.9755/ ejfa.2019.v31.i5.1955

Araújo Filho JA, editor. Manejo pastoril sustentável da Caatinga. $1^{\text {a }}$. ed. Recife: Projeto Dom Helder Camara; 2013. ISBN 9788564154049.

Araújo MM, Navroski MC, Schorn LA, editores. Produção de sementes e mudas: um enfoque à silvicultura. $1^{\text {a }}$. ed. Santa Maria: Editora UFSM; 2018. ISBN 9788573913156

Asghar MA, Jiang H, Shui Z, Cao X, Huang X, Imran $S$, et al. Interactive effect of shade and PEGinduced osmotic stress on physiological responses of soybean seedlings. Journal of Interactive Agriculture. 2021;20(9):2382-2394. doi: 10.1016/S2095$3119(20) 63383$

Ballaré CL, Pierik R. The shade-avoidance syndrome: multiple signals and ecological consequences. Plant, Cell \& Environment. 2017;40(11):2530-2543. doi: 10.1111/pce. 12914
Bessa MC, Lacerda CF de, Amorim AV, Bezerra AME, Lima AD. Mechanisms of salt tolerance in seedlings of six woody native species of the Brazilian semi-arid. Revista Ciência Agronômica. 2017;48(1):157-165. doi:10.5935/18066690.20170018

Campelo DH, Lacerda CF de, Sousa JA de, Correia D, Bezerra AME, Araújo JDM, et al. Leaf gas exchange and efficiency of photosystem II in adult plants of six forest species as function of the water supply in the soil. Revista Árvore. 2015;39(5):973983. doi: 10.1590/0100-67622015000500020

Campos Filho EM, Sartorelli PAR. Guia de árvores com valor econômico. $1^{\mathrm{a}}$. ed. São Paulo: Agroicone; 2015. ISBN 9788556550002

Carvalho PER. Espécies Arbóreas Brasileiras. 1a ${ }^{\mathrm{a}}$ ed. Brasília: Embrapa; 2003. v.1. ISBN 9788573831672

Cavalcante ES, Lacerda CF de, Costa RNT, Gheyi HR, Pinho LL, Bezerra FMS, et al. Supplemental irrigation using brackish water on maize in tropical semi-arid regions of Brazil: yield and economical analysis. Scientia Agricola. 2021;78(suppl 1):1-9. doi: 10.1590/1678-992X-2020-0151

César FRCF, Matsumoto SN, Viana AES, Bonfim JA. Initial growth and quality of Pterogyne nitens Tull. seedling under artificial shading gradient. Ciência Florestal. 2014;24(2):357-366. doi: $10.5902 / 1980509814573$

Dickson A, Leaf AL, Hosner JF. Quality appraisal of white spruce and white pine seedling stock in nurseries. The Forestry Chronicle. 1960;36(1):10-13. doi: $10.5558 / \mathrm{tfc} 36010-1$

Echer FR, Zanfolin PRL, Moreira ACM, Santos ACP, Gorni PH. Root growth and carbohydrate partitioning in cotton subjected to shading in the initial phase. Ciência Rural. 2019;49(1):1-8. doi: 10.1590/0103-8478cr20180749

Ferreira DF. Sisvar. Versão 5.7. Lavras: UFLA/DEX; 2014.

Felsemburgh CA, Santos KJS dos, Camargo PB de, Carmo JB do, Tribuzy ES. Ecophysiological responses of Aniba parviflora under artificial shading. Pesquisa Florestal Brasileira. 2016;36(87):201-210. doi: 10.4336/2016. 
pfb.36.87.964

Freire MHC, Sousa GG de, Ceita EDR, Barbosa AS, Goes GF, Lacerda CF de. Gas exchange of fava bean varieties under salinity conditions of irrigation water. Agrarian. 2021;14(51):61-70. doi: 10.30612/ agrarian.v14i51.11958

Freitas MAC, Amorim AV, Bezerra AME, Pereira MS, Bessa MC, Nogueira Filho FP, et al.Growth and salinity tolerance in three medicinal species of the genus Plectranthus exposed to different levels of solar radiation. Revista Brasileira de Plantas Medicinais. 2014;16(4):839-849. doi: 10.1590/1983084X/12_152

Freitas VMB, Scalon SPQ, Dresch DM, Bastos SS, Souza APR de, Junglos FS. Emergence, initial growth and photosyntetic metabolism of Ormosia arborea (Vell.) Harms under different light availabilities. Floresta. 2020;50(4):1689-1697. doi: 10.5380/rf.v50i4.58541

Gonçalves EZ, Paiva HN de, Neves JCL, Gomes JM. Nutrition of red angico seedlings (Anadenanthera macrocarpa (Benth.) Brenan) under different macronutrient doses. Revista Árvore. 2012;36(2):219-228. doi: 10.1590/S010067622012000200003

Instituto Nacional de Meteorologia - INMET. Tabela de dados da estação Fortaleza A305. 2020. [cited 2021 June 05]. Available from: https://tempo. inmet.gov.br/TabelaEstacoes/A305.

Kumar M, Kumar R, Jain V, Jain S. Differential behavior of the antioxidant system in response to salinity induced oxidative stress in salt-tolerant and salt-sensitive cultivars of Brassica juncea L. Biocatalisys and Agricultural Tecnology. 2018;13(1):12-19. doi: 10.1016/j.bcab.2017.11.003

Lacerda CF de, Gheyi HR, Medeiros JF, Costa RNT, Sousa GG de, Lima GS. Strategies for the use of brackish water for crop production in Northeastern Brazil. In: Taleisnik E, Lavado RS, editores.

Saline and alcaline soils in Latin America: natural resources, management and productive alternatives. $1^{\mathrm{a}}$. ed. Springer International Publishing; 2021. p. 7199. ISBN 9783030525927

Lima AD, Bezerra FMS, Neves ALR, Sousa CHC de, Lacerda CF de, Bezerra AME. Response of four woody species to salinity and water deficit in initial growth phase. Revista Brasileira de Engenharia Agrícola e Ambiental. 2018a;22(11):753-757. doi: 10.1590/1807-1929/agriambi.v22n11p753-757

Lima BLC, Lacerda CF de, Ferreira Neto M, Campelo DH, Silva JA, Ortiz PFS, et al. Light availability and salt stress on Hazel sterculia seedlings. Floresta e Ambiente. 2018b;25(4):1-8. doi: $10.1590 / 2179-8087.056717$

Long SP, Humphries S, Falkowski PG.

Photoinibition of photosynthesis in nature. Annual Review of Plant Physiology and Plant Molecular Biology. 1994;45:633-662. doi: 10.1146/annurev. pp.45.060194.003221

Matias JR, Torres SB, Leal CCP, Leite MS, Carvalho SMC. Hydropriming as inducer of salinity tolerance in sunflower seeds. Revista Brasileira de Engenharia Agrícola e Ambiental. 2018;22(4):255-260. doi: 10.1590/1807-1929/agriambi.v22n4p255-260

Medeiros JF. Qualidade da água de irrigação e evolução da salinidade nas propriedades assistidas pelo "GAT" nos estados do RN, PB e CE. Dissertação de Mestrado. 1992;

Morais RR, Rossi LMB, Higa RCV. Gas exchange of seedlings of taxi-branco subbimited to leaf temperature variation and irrigation suspension. Ciência Florestal. 2017;27(1):97-104. doi: $10.5902 / 1980509826450$

Neves ALR, Lacerda CF de, Oliveira AC, Sousa CHC, Oliveira FIF, Ribeiro MSS. Quantitative and qualitative responses of Catharanthus roseus to salinity and biofertilizer. Revista Brasileira de Engenharia Agrícola e Ambiental. 2018;22(1):22-26. doi: 10.1590/1807-1929/agriambi.v22n1p22-26

Pacheco FV, Pereira CR, Silva RL, Alvarenga ICA. Initial growing of Dalbergia negra (Vell.) Allemão ex. Benth. (Fabaceae) e Chorisia speciosa A.St.Hil (Malvaceae) at different levels of shadeRevista Árvore. 2013;37(5):945-953. doi: 10.1590/S010067622013000500017

Perdomo JA, Capó-Bauça S, Carmo-Silva E, Galmés J. Rubisco and rubisco activase play an important role in the biochemical limitations of photosynthesis in rice, wheat and maize under high temperature and water deficit. Frontiers in Plant Science. 2017;8(1):1- 


\section{5. doi: 10.3389/fpls.2017.00490}

Rhoades JD, Miyamoto S. Testing soils for salinity and sodicity. In: Westerman RL, editor. Soil testing and plant analysis. $3^{\mathrm{a}}$. ed. Madison: Soil Science Society of America; 1990. ISBN 9780891188452

Rivas R, Barros V, Falcão H, Frosi G, Arruda E, Santos M. Ecophysiological traits of invasive C3 species Calotropis procera to maintain high photosynthetic performance under high VDP and low soil water balance in semi-arid and seacost zones. Frontiers in Plant Science. 2020;11(1):1-16. doi: 10.3389/fpls.2020.00717

Santos MG, Oliveira MT, Figueiredo KV, Falcão HM, Arruda ECP, Almeida-Cortez J, et al. Caatinga, the brazilian dry tropical forest: can it tolerate climate changes?. Theoretical and Experimental Plant Physiology. 2014;26:83-99. doi: 10.1007/ s40626-014-0008-0

Scalon SPQ, Kodama FM, Dresch DM, Mussury RM, Pereira ZV. Gas exchange and photosynthetic activity in Hancornia speciosa gomes seedlings under water deficit conditions and during redydration. Bioscience Journal. 2015;31(4):11241132. doi: 10.14393/BJ-v31n4a2015-26088

Silva ARA, Bezerra FML, Lacerda CF de, Sousa CHC, Bezerra MA. Physiological responses of dwarf coconut plants under water deficit in salt-affected soils. Revista Caatinga. 2017;30(2):447-457. doi: 10.1590/1983-21252017v30n220rc

Silva BEP, Costa AVL, Simmi FZ, Reolon F, Deuner S. Physiological and photosynthetic parameters of white oats submitted to salinity. Revista Científica Rural. 2019;21(1):60-71. doi: 10.30945/rcrv21i1.303

Silva FJA, Araújo AL, Souza RO. Águas subterrâneas no Ceará - poços instalados e salinidade. Rev. Tecnol. Fortaleza. 2007;28(2):136-159
Silva GS, Dutra WF, Dutra AF, Oliveira IM, Filgueiras LMB, Melo AS. Gas exchange and chlorophyll fluorescence of eggplant grown under different irrigation depths. Revista Brasileira de Engenharia Agrícola e Ambiental. 2015;19(10):946952. doi: 10.1590/1807-1929/agriambi. v19n10p946-952

Silva LA, Brito MEB, Sá FVS, Moreira RCL, Soares Filho WS, Fernandes PD. Physiological mechanisms in citrus hybrids under saline stress in hydroponic system. Revista Brasileira de Engenharia Agrícola e Ambiental. 2014;18(suppl.):1-7. doi: 10.1590/18071929/agriambi.v18nsuppS1-S7

Taiz L, Zeiger E, Moller IR, Murphy A, editores. Fisiologia e desenvolvimento vegetal. $6^{\mathrm{a}}$. ed. Porto Alegre: Artmed; 2017. ISBN 9788582713679.

Tan Z-H, Zeng J, Zhang Y-J, Slot M, Gamo M, Hirano T, et al. Optimum air temperature for tropical forest photosynthesis: mechanisms involved and implications for climate warming. Environmental Research Letters. 2017;12(5):1-12. doi: 10.1088/1748-9326/aa6f97

Urban L, Aarrouf J, Bidel LPR. Assessing the effects of water deficit on photosynthesis using parameters derived from measurements of leaf gas exchange and of clorophyll a fluoresence. Frontiers in Plant Science. 2017;8(1):1-18. doi: 10.3389/ fpls.2017.02068

Yuan C, Feng S, Huo Z, Ji Q. Effects of deficit irrigation with saline water on soil water-salt distribution and water use efficiency of maize for seed production in arid Northwest China. Agricultural Water Management. 2019;212(C):424432. doi: 10.1016/j.agwat.2018.09.019

Zelm EV, Zhang Y, Testerink C. Salt tolerance mechanisms of plants. Annual Review of Plant Biology. 2020;71:403-433. doi: 10.1146/annurevarplant-050718-100005 